\title{
Materializing Notions, Concepts and Language into Another Linguistic Framework
}

\author{
Anne Wagner · Jean-Claude Gémar
}

Published online: 7 November 2013

(C) Springer Science+Business Media Dordrecht 2013

Je suivais mon objet sans former de dessein; je ne connaissais ni les règles ni les exceptions; je ne trouvais la lumière que pour la perdre.

(Montesquieu, L'Esprit des Lois)

The Speculative Rhetoric aspect of the study of signs and their processes, interrelations and forces becomes a kind of alchemical crucible for the transformation of traditional meaning of terms, such that the older rhetorical strategies assume unprecedented function and representation. The older notion of a rhetorical invention becomes a process tantamount to the creating of a new reality: an emergent worldfact.

[37: 18]

Conceptualizing two distinctive cultural elements has become a significant framework in legal discourse analysis and legal translation. It strives for rational clarity, objective justification and textual precision. Indeed, materialization is an act of cross-cultural communication, which implies matching cultural elements of two different languages rather than only considering the linguistic elements:

New disciplines emerge not only as knowledge grows and spreads but also as power relations and reputations change within academia. Historically, new disciplines have often emerged at the interface of existing ones, and so at first they inevitably have the nature of interdisciplines. [...] Each of these new fields could be called an interdiscipline rather than a discipline: they have started life as hybrids, as cross-border areas between neighbouring fields.

\footnotetext{
A. Wagner $(\bowtie)$

Centre Droits et Perspectives du droit, équipe René Demogue, Université Lille—Nord de France, Lille, France

e-mail: valwagnerfr@yahoo.com

J.-C. Gémar

Professeur émérite, Université de Montréal, Montreal, Canada

J.-C. Gémar

Professeur émérite, Université de Genève, Geneva, Switzerland
} 
Indeed, these new fields query the very borders they straddle, challenging us to think in different ways [6: 4].

Conceptualisation into another language not only means to use the simple mechanism of translation, but also to proceed to the translabiliting process in order to materialize notions and concepts into another linguistic framework.

Translability aims at comprehension, whereas encounters between cultures or interactions between levels of culture involve either assimilation or appropriation by making inroads into one another, trying to get out of a different culture or the different intra-cultural levels that seem attractive, useful, or is combated and suppressed for whatever reasons [35: 6].

The collocation "materialization" emphasizes the link between the process of conceptualisation and the framework of law. It points to their mutual influences and to the adjustment in the legal transfer process. Adjustment of concepts, notions and language is vital as law is always evolving with on-going transformations of concepts and notions within space and time. The content of concepts and notions can change, with the words amplified by new meanings. In their turn, features of law influence the procedure of materialization in the creativity of law and in its application. This impact of the creation and the adjustment process should be taken into consideration regarding the implementation of new concepts and notions:

In law, although all cases of law application refer to some facts, which are brute facts in that sense and at that level, the legal process is one characterized by transformations of these facts into institutional facts, by interpreting them in the light of relevant rules and conventions. [41: 220]

Materialization is subject to stringent constraints at all levels, and the act of transferring the source knowledge into the target knowledge is far from being an easy task. Conceiving law as a system of signs allows the understanding of how that process works and how we can connect our life to the text of the law [38: 4]. Likewise, materializing legal knowledge from one language to another is not a static mechanism, but rather a living process deriving from the "living monster", which is law (Bentham). This transfer in the sense of traversing linguistic barriers should fit the representation setting. But,

The chief problem ... will always be, not the individual état de langue, but the relationship between different stages of a single language and between different languages, their similarities and their differences [34: 9].

Materializing notions, concepts and language into another linguistic framework implies "an overlapping of segments of disciplines, a recombination of knowledge in new specialized fields" [15: 435]. Besides, consciousness, motivation, and social perception play an important role in interpreting the truth of statements, in construing concepts, notions and language:

Motion and motivation are recovered with respect to their radical relations in evolving meaning. They are presented as ideas revealing interwoven etymological, historical and semiotic non-Euclidean parallel growth: a 
turning, crossing, intersecting network of association in meaning that becomes even more complex with each evolutionary turn [37: 39].

Translating and transferring law, its concepts and notions into another linguistic framework reveal that the "relationship between the inscribed words that constitutes the rule in its bare propositional form and the idea to which they are connected is largely arbitrary in the sense that it is culturally determined" [39: 36]. Furthermore, "every culture that has faith in itself tends to spread its own institutions. Anyone with the power to do so tends to impose his own upon others" [48: 398]. Accordingly, the process of translabiliting is a multi-levelled maze [18: 86] in which communication in law reveals a complex network of interactions between the individuals and their environment. The past is seen in its continuity with the present - which is exactly what the jurist does in his practical, normative work of "ensuring the unbroken continuance of law and preserving the tradition of the legal idea" [24: 327].

Legal language roots meanings of words in relative stability-in a legal text. It strives for precision in language usage and in the context of the general polysemy of words it performs the tasks of explaining meanings of words. Although in law, the explanation of words is also part of the legal regulation that is endowed with the same legal force as any other part in the specific legal text, the binding character of language in law is nonetheless still indirect in the sense that its usage is not a general requirement for human communication in daily life. It becomes binding in situations that should be resolved in legal terms when it is applied as an instrument to specific reality:

Words have the meanings they have in a language because of their relations to other words, because of their contrasts and affinities, and because of the dense historical and social vocabulary they help to constitute and to which they belong. But they also have the meanings they have because of their relations to contexts of possible action and social practice. At the same time, the meaning of these actions and practices themselves depend upon the availability of a certain vocabulary of concepts and ideas [61: 17].

Likewise, if we consider the European perspective, legal communication is even more complex and needs to find out equivalences in meaning. Monjean-Decaudin [43: 700] refers to the inevitable "équivalence uniformisante" in the EU Legal order. MacAuliffe [42: 107] points out that "EU law is a legal system built from approximations of law and language from different legal cultures and different legal languages, which come together to form a new supranational legal system with its own language". Legal language is a specific legal genre and its peculiarities include force, sanctions and status. Legal language is a prominent testimony of legal history, a source of the study of the society and culture which, alongside the message about a legal order that has existed or exists, includes indications how things, phenomena, processes are designated by words, what terms have been used in the creativity of law, in the practice of applying law, and in the doctrine of law:

Les mots sont intelligibles seulement si l'on admet l'hypothèse d'un contexte de production de l'intention, d'une pré-décision déjà en place de la part de la 
personne qui est en train de parler ou d'écrire [...] les sens ne sont pas enfouis dans les mots mais surgissent et deviennent clairs à la lumière des conditions de fond et d'intelligibilité qui les entourent [21: 150].

\section{Langage du droit, Culture et traduction}

$\mathrm{Si}$, selon les théoriciens du langage, la fonction principale de l'opération de traduction est de produire un acte de communication, traduire est avant tout un acte de foi du traducteur, foi dans le succès de la communication interlinguistique. Et cela malgré les obstacles que les langues et les auteurs de textes dressent sur sa route: polysémie, ambiguiité, technicité du vocabulaire, lourdeurs et maladresses, profusion, etc. Autant de parasites s'interposant entre le texte et son lecteur qui sont susceptibles de perturber, dégrader, voire de bloquer la communication, et donc le sens.

Traduire, "an exact art" [55: 311], est chose ardue. Mais traduire des textes juridiques au Canada l'est plus encore, car "là où ils s'additionnent, le bilinguisme et le bijuridisme portent au paroxysme la complexité" [7:13].

Faut-il en conclure que traduire des textes à contenu juridique dans un contexte de bilinguisme et de bijuridisme-celui du Canada, par exemple-est chose quasi impossible? On pourrait être tenté de le croire, et de fait nombreux sont les auteurs, parmi les juristes notamment (voir Legrand), qui le pensent. Il est vrai que le langage du droit véhicule des notions, abrite des institutions et des procédures qui sont tellement propres à chaque langue et culture juridiques que l'on ne peut les transposer telles quelles d'une langue et d'un système dans une autre langue et un autre système sans risquer à tout moment l'impropriété, le contresens voire le nonsens juridiques [8], [47: 169]; [57, 63].

Il s'ensuit que la traduction juridique, tout particulièrement entre le français et l'anglais, pose un problème particulièrement aigu au traducteur dans la mesure où il ne s'agit pas seulement de passer d'une langue à une autre, mais d'un système de droit à un autre [14]. La loi s'inscrit dans une tradition d'écriture, autrement dit une culture. Si "les lois naturelles fédèrent les choses", les règles sociales "lient les hommes" [51: 169]. Cette évidence saute aux yeux dès lors que l'on compare la manière dont les codes français sont composés (sur le modèle du Code Napoléon) à la façon anglo-américaine de codifier les lois-ce qui inclut le Canada (voir son Code criminel). Elles sont aux antipodes l'une de l'autre. Ce n'est pas affaire de langue ni de mots, mais de tournure d'esprit, de différence essentielle de vues et de conceptions, notamment entre le général et le particulier retenus comme fondement de la pensée et de l'édifice juridiques. Serait-ce dû à la façon dont les systèmes juridiques se sont édifiés autour de l'axe fondamental des deux grandes traditions: droit "écrit" (droit romain et ses avatars)/droit "non écrit" (common law angloaméricaine)? Ou bien, plutôt, à l'organisation des sociétés et à leur "logic of writing" [32] qui en seraient la cause? Aussi le sens du message-juridique ou autre-que porte le texte est-il intimement lié à la culture qui l'a produit [2]. 


\section{Forme du texte juridique et jurilinguistique}

Le droit est exprimé de nombreuses façons au sein d'une même langue et de chaque système [27], selon le mode d'intervention que la société lui a confié (loi, jugement, contrat, etc.). Aussi n'est-il pas étonnant, lorsque le texte de droit est transposé d'une langue à l'autre et, parfois, projeté dans un système juridique très différent comme au Canada, qu'il en ressorte transformé, en bien ou en mal. La composition des textes, la logique de leur exposition variant d'une langue à l'autre, cette transformation apparaît d'emblée dans la forme, donc dans la manière de rédiger. Historiquement, dans le système de la common law, la procédure a longtemps primé le droit : remedies precede rights [13: 329]. La trace en subsiste dans les systèmes contemporains et les textes que produisent leurs juristes et leurs institutions. Comme le souligne Bryan Garner (parodiant Robert Frost), bien que le rédacteur juridique s'efforce d'atteindre "a momentary stay against confusion", "certainty is the paramont aim of the drafstman rather than attractive legal style" [25: 336]. La précision du droit passe avant l'élégance de l'expression, principe dirimant auquel doit se plier le traducteur.

Dans le système civiliste, où règne la règle de droit, c'est le contraire qui prévaut: "Au commencement était la Règle" clame Carbonnier [4: 96]. Mais la façon dont cette règle est exprimée en détermine le sens et la portée.

La transformation de la forme du texte juridique, lorsqu'il passe au crible de la traduction, n'est pas sans conséquence sur le fond. Par le truchement de l'opération traduisante et en inversant la formule ("le droit prime la procédure"), lorsque l'on traduit de l'anglais vers le français, c'est en théorie le droit, soit la règle et son expression, qui prime alors dans l'esprit sinon dans la lettre, et non plus la procédure et ses modes d'expression. Il s'ensuit que, lors du transfert du texte de départ anglais vers le texte d'arrivée français_ — ou vice versa: le contraire est tout aussi vrai -, un obstacle épistémologique d'importance s'interpose entre les systèmes et leurs présupposés. Par-delà termes et notions, le texte traduit peut y gagner en sens par l'effet 'plus-disant' du système de départ, ou en perdre par l'effet 'moins-disant' de ce même système. N'étant pas exprimé dans le même esprit que le texte de départ—pour ne rien dire de la lettre -, le texte en est modifié dans ses fondements mêmes: le droit.

Ce constat découle d'une longue pratique des textes juridiques et de leur traduction, rodées au double langage du droit en contexte de bilinguisme et de bijuridisme. Il est également partagé, au moins en partie, par des juristes dans l'analyse des rapports que la forme peut entretenir avec le sens au sein du texte juridique [29, 36]. Si le style d'expression d'un droit lui est si intimement associé que son « esprit » arrive à en être confondu avec sa lettre [49: 47], alors le sens du texte juridique passe aussi par la forme du message, mais d'une manière plus subtile, fine et légère que par son seul contenu. En découle ce que Roland Barthes appelle la "signifiance", ou sens profond, caché, du texte. $\mathrm{Si}$, comme le laisse entendre Kasirer [36: xiii], l'application (common law) fait plus que la règle (droit civiliste), les exemples instruiraient-ils mieux que les préceptes? La réponse relève davantage de la didactique, de la philosophie, que du droit.

La formulation d'un texte, la manière de le rédiger (le style) traduit une personnalité, souvent reconnaissable au premier coup d'œil: Shakespeare, Jane 
Austen, Agatha Christie ou Le Carré, d'un côté, Racine, Hugo, Balzac ou Proust, de l'autre. Le style d'un code civil n'est pas celui du journalisme, de la Bible ou d'un poème. Rédiger un texte relève en outre d'une stratégie de communication qu'établit l'auteur, individu ou collectif (l'État). Dans son expression, écrite ou verbale, le droit est soumis aux mêmes servitudes linguistiques que tout acte de langage, quoi que puissent en penser les juristes, toujours prompts à voir dans leur domaine et ses écrits une exception à la règle commune.

Ici intervient la jurilinguistique, qui est l'application d'un traitement linguistique aux textes juridiques sous toutes leurs formes [28: 135]. Elle met à la disposition des langagiers une batterie d'outils et de moyens pour rédiger, réviser, améliorer les textes juridiques, avec pour but d'en faciliter la lecture et la compréhension. La jurilinguistique est née et s'est développée au Canada dans le dernier tiers du XX siècle. Pour des raisons tenant à son histoire, ses langues et ses traditions juridiques, le Canada a joué un rôle de pionnier dans l'évolution de cette discipline, qui est issue d'une pratique séculaire de la traduction. Née sous la pression des besoins de communication et de diffusion de l'Etat moderne, puis de la société civile, elle transcende les frontières des langues et les barrières des traditions juridiques. Un corps de doctrine se constitue progressivement, contribuant à édifier un savoir d'un genre nouveau. Il caractérise une discipline qui se situe aux marges et à la croisée du droit et de la linguistique, appliquée et théorique. Ses fonctions sont liées à la pratique du droit, à son évolution et à sa communication.

\section{Forme, Signification et sens du texte: une sémiotique juridique ?}

Nous vivons entourés de signes que nous interprétons par le canal de nos sens. Mais nous ignorons le jeu des mécanismes qui permettraient de comprendre le sens profond des interrogations qui sollicitent notre intelligence. Loin de pouvoir réaliser la synthèse complète de ses multiples composantes (Nature + Culture), nous évoluons en permanence sur l'écume du sens. Bloqués au seuil de sa porte, nous n'en effleurons que la surface sans parvenir à pénétrer dans son intimité, dans sa "structure profonde" (Chomsky).

Le sens et l'interprétation qu'en fera une personne dépendent de la lecture des signes composant un texte. Or cette lecture nous est aussi personnelle que notre façon de marcher, d'écrire ou de parler. L'interprétation d'un texte, soit le sens que nous lui donnons à la suite de cette opération d'élucidation de ses diverses composantes, est, comme on le pense intuitivement, unique, attachée à l'individu interprétant. Il en va de même, lorsque ce texte est traduit, pour sa réexpression et la manière dont il sera rédigé. Le texte d'arrivée est aussi propre à une personne que son code génétique ou ses empreintes digitales puisqu'il procède de l'interprétation personnelle qu'elle a faite du texte de départ pour en comprendre le sens du message et le réexprimer selon ce qu'elle pense en avoir compris, conformément à sa destination et de la manière qui lui est habituelle. 
À mesure que le lecteur-traducteur progresse de la signification des parties (les fragments : les mots) vers le tout (sens du message), le dénominateur commun des mots du texte se resserre. Universel au départ, il devient, à l'arrivée, particulier voire spécialisé, car dicté par le contexte. Selon le degré de savoir-faire et de connaissances du lecteur ou du traducteur-car tout le monde n'y accède pas également -, le sens sera plus ou moins réduit au plus petit commun dénominateur. Si l'on compare le sens à un angle, de plat (ouvert) au départ, il sera aigu (réduit) à l'arrivée, lorsque le sens jaillira de la confrontation, du dialogue entre le texte et son interprète. Au terme de ce parcours, à la suite de cet échange, muet mais vif et intense, après avoir déterminé le vouloir-dire du texte, quel que soit le but visé (ludique, professionnel, traduction, recherche, etc.), le lecteur ou le traducteur s'efforce d'en "(re)construire" le sens. Le résultat (la 'performance') de ses efforts est lié à sa 'compétence' (son savoir-faire). Le sort du sens du texte dépend de la valeur de celle-ci.

Ce schéma général de l'intelligence du sens s'applique à tout genre de texte, texte juridique compris, parce que celui-ci ne déroge ni aux lois du langage ni à la langue particulière qui l'exprime, anglais ou français, et dont il constitue un sous-ensemble, une "langue spécialisée" [40].

\section{Le Message du texte juridique ou l'incertitude du sens}

Faut-il en conclure que le sens que porte le message juridique, étant dû à une interprétation et à une formulation personnelles, est un sens en suspens, rarement fixé d'emblée? C'est le sentiment d'un Elmer A. Driedger [16: ix] pour qui “[a]ll statutes must be 'construed". La signification des mots, "objective" dans les dictionnaires, reste incertaine tant qu'elle n'est pas tranchée dans un litige, lieu du " subjectif" (prétention des parties) par excellence. Le langage du droit, produit d'une pensée qu'Aurel David [12: 33] a taxée de "naïve" (entendre: 'primitive'), est inachevé dans sa réalisation: le texte, puisque son sens est en suspens. Il n'advient pleinement que dans une infime minorité de cas par rapport au nombre incalculable de textes juridiques que produit la société. N'étant pas exposés au litige, ils ne sont pas soumis à la justice, qui dirait le droit, et donc le sens à donner au message juridique. Dans l'immense majorité des cas, le sens continuera de flotter entre les diverses interprétations, juridiques comme textuelles, qu'il est possible d'en faire, puisque, pour François Ost et Michel van de Kerchove, "aucun texte ne peut prétendre détenir un sens unique" [45: 165].

Loin d'être deux entités distinctes, la forme et le fond sont confondus au sein du texte. Et cela parce que les mots, une fois mis en discours, qu'elle qu'en soit la forme, véhiculent un message-juridique, économique, médical, littéraire, philosophique, etc.- dans un texte porteur d'un sens dont la forme et le fond sont codépositaires. Peut-être à parts égales (entre Nature et Culture?), si tant est qu'il y ait une forme et un fond "parce qu'il n'y a ni forme, ni fond [...] Le fond est la forme, la forme est le fond" [11: 839]. Le droit évoluant plus lentement que la langue, son langage parfois ésotérique est souvent en décalage avec celui de la société qui le produit. À moins qu'il ne s'agisse, finalement, comme le pense Pierre Lerat (infra), 
qu'affaire de culture : «L'ésotérisme du droit n'est pas dû à son vocabulaire, comme on le croit souvent. Il est dû à la culture qui rend intelligibles les textes juridiques, c'est-à-dire à des connaissances présupposées. » .

Cela ne freine pas l'ardeur des nombreux mouvements et tentatives de simplification des textes juridiques (plain language law) auxquels on assiste depuis quelques décennies, lancés particulièrement dans les pays anglo-saxons pour s'efforcer de rendre le message du droit et de la justice plus lisible et accessible aux citoyens [10, 20]: 161].

Toutefois, lorsque le texte de loi est traduit ou co-rédigé, comme au Canada ou en Suisse, quel que soit le traitement jurilinguistique qu'il a reçu, qui décide de son équivalence de sens dans l'autre texte? Les tribunaux, généralement. Par l'interprétation, le juge recherche l'intention de l'auteur ou des auteurs du texte, le sens que l'on a voulu donner aux mots, à la disposition d'une loi, à la clause d'un contrat, mais cela en vue de « dire le droit». Au Canada, le traducteur (ou le légistecorédacteur) joue un rôle non négligeable d'interprète du texte en vue de le traduire, alors que le juge est l'interprète du droit et de son message. Il ne reste plus au traducteur qu'à introduire cet "excès de clarté" que Gadamer lui prête [17: 130].

\section{Materializing Notions, Concepts and Language}

Law is a social phenomenon having multiple (or comprehensive) philosophical, theoretical and historical roots. Meanings in law have cultural nuances according to the systems of lifestyle, values, traditions and collective memory that are being examined. Law conveys testimony of the past but also an ongoing social process that could be adjusted within space and time [59]. Likewise, law reflects human values, practices, and aspirations of changes as its boundaries are flexible and in constant evolution. As expressed by Cao [3: 23] "law and legal language are system-bound, that is, they reflect the history, evolution and culture of a legal system".

It therefore seems logical to make prospective translators, jurilinguists, lawyerslinguists "fit" for a wide range of technical producing activities, providing them not only with a solid text-based competence, but also with a solid societal knowledge of both the source and target languages. Several tasks are identified with the aims:

1 to examine the process of the introduction of the new term or concept and to highlight the relevant related theoretical aspects as well as to describe the specific contextual peculiarities of its usage in the area of law in the source language;

2 to analyse the explanation provided for this term or concept in the law and to reveal aspects of the origin of the diversity of its meanings as well as its integration into the structure of the language of law in the source language;

3 to assess and identify potential difficulties for its transfer and interpretation as well as for the achievement of its translation (its fertilization) into the target language.

It is neither the case that interpretation is constrained by what is obviously and unproblematically 'there', nor the case that interpreters, in the absence of such 
constraints, are free to read into a text whatever they like... Interpreters are constrained by their tacit awareness of what is possible and not possible to do, what is and is not a reasonable thing to say, what will and will not be heard as evidence in a given enterprise, and it is within those same constraints that they see and bring others to see the shape of the documents for whose interpretation they are committed [22: 555].

Communicating in law empowers a "cultural turn" [52], and has progressively engaged in an "interdisciplinary turn" [30: 11], and a "technological turn" [9].

Our special issue will focus on three main axes. (1) Materializing notions, concepts and language into another linguistic framework is subject to a series of doctrinal influences to be further discussed by our contributors: Pierre Lerat, JeanLouis Sourioux, Pierre Brunet and Pierre Moor. (2) Legal discourse is a cross-border area between neighbouring fields and this hypothesis will be analyzed within the following contributions drafted by Pierre Legrand, Michel van de Kerchove, Li Li and Karen McAuliffe. (3) Nonetheless, communicating in law shapes the emergence of an interdisciplinary discipline-jurilinguistics - with concerns on communication to grasp and convey cultural nuances distilled within concepts, which will be developed through case analyses in different legal systems by Wang Ling \& King Kin Sui, Rafat Y. Alwazna, James Brannan and King Kui Sin.

\subsection{Series of Doctrinal Influences}

Law is a symbolic construction and therefore rests on a variety of undertakings. What gives law its meaning is, for some, ideology; for others, it corresponds to the welfare of the majority. However what is manifest is a conception of the law as a material structure that carries symbols of everyday life. That analyses that are make in the law and semiotics movements show that the law's symbolism cannot be understood by reference only to itself, a strictly 'legal' meaning. It is a symbol that conveys life, a symbol that in itself is contaminated with life, politics, morality and so on. Notions, concepts are expressed in words. Words must be capable of expressing law in a clear and understandable manner using different disciplines. Combining generalisation and precision is one of the most serious challenges in law. Law refers to the diversity of former and actual social and professional practices. Words should be used to guide lay people as well as professionals with a sufficient degree of clarity. The language of the law has the capacity of creating, innovating, and distilling new ideas into a word. This capacity of distilling new meanings into former words and/or of creating new ones is crucial. The practical usefulness in the creation and application of law address the fundamental role of language in law and in the society. Law is embodied in language and thus language is the instrument and foundation of law.

Legal language is in constant interaction with general language usage. Influences are mutual. Law serves as one of the essential references for the explanation of words. Law is the result of creativity and has at its foundation human skills that have developed in the course of history. Likewise, it reflects and consolidates as well as forms and transforms-directly and indirectly_-value perceptions that exist in the 
society and are historically changing [31, 60]. Yet, scholarship has acknowledged that constructing the meaning of legal language is not alone subject to many societal mutations as legal language itself can be slippery, fluid, and highly unpredictable $[44,54,56]$.

Pierre Lerat est professeur honoraire à l'université de Paris-Nord (Paris XIII) et un spécialiste de langage juridique. Partant de l'idée qu'il faut distinguer ce qui est partagé (connaissances entre experts) de ce qui ne l'est pas, il propose une méthodologie reposant sur le partage des conceptualisations comme moyen de dépasser les différences linguistiques afin de rendre le droit opératoire. Un vocabulaire juridique fondamental, commun à la plupart des systèmes, permet de partager et ainsi de transmettre un fonds minimal de concepts. Cette démarche passe d'abord par une approche onomasiologique (niveau global) avant de s'appliquer au niveau local, là « où les mots sont traités comme tels ».

Jean-Louis Sourioux est Professeur émérite de l'Université Panthéon-Assas (Paris II). Ses travaux portent notamment sur le langage du droit, ses mots et concepts et ses fonctions langagières. Le Professeur Sourioux reprend ici le concept d'herméneutique philosophique que l'on doit à Gadamer et qui repose sur l'interprétation envisagée comme forme explicite de la compréhension. Ce concept a fait débat sur l'herméneutique contemporaine au sujet des textes rédigés à des périodes différentes de celles où ils sont appliqués. En découle le problème du langage à l'œuvre dans l'acte d'interprétation qui ne saurait laisser indifférent le juriste, interprète de la loi par le biais de sa langue spécialisée.

Pierre Brunet est professeur de droit public à l'Université de Paris Ouest Nanterre où il dirige le Centre de Théorie et Analyse du droit. Son analyse porte sur le raisonnement juridique et la façon dont raisonnent les juristes. Le droit est-il une «pratique sociale » ou un « ensemble de normes»? Les deux grandes traditions juridiques, common law et droit civiliste, disputent autour de la question de la spécificité du raisonnement juridique et sur l'essence de la raison, « artificielle » (Coke) pour la première, affaire d'analogie et de précédent, et pour la seconde, affaire de rationalisme et de démarche déductive («mos geometricus » chez Domat). Si le droit est une pratique sociale, elle est donc partagée. On peut alors s'interroger sur la position de chacun des intervenants (juges, doctrine, avocats) dans cette pratique.

Pierre Moor est Professeur honoraire à l'Institut de droit public de l'Université de Lausanne. Son étude présente la théorie du droit comme sémiotique juridique et sous l'angle du fonctionnement de l'ordre juridique, particulièrement dans ses relations avec son environnement. L'analyse part du principe que le droit est une praxis, non un édifice de normes mais un travail de production de sens. L'effet performatif de l'acte de langage « dire » (le droit) fait qu'un texte est ipso facto transformé en texte juridique. L'ensemble des normes est produit par des acteurs qualifiés. Figures de l'ordre juridique par lesquels passe le flot de l'information, ils sont à la fois acteurs sociaux et constructions normatives voués à relier deux mondes séparés. 


\subsection{A Cross-Border Area Between Neighbouring Fields}

Like any language act, legal translation is the result of a compromise, of a "negotiation" [18]. Transferring legal knowledge is not a static mechanism but rather a "living reality" [31]. This transfer in the sense of traversing linguistic barriers should fit the representation setting.

Materialization is a difficult task, as it is an endogenous process. Indeed, "the content and meaning of law is determined within the social field that is designed to regulate" [19: 407], but similarly to law it remains "uncertain, indefinite and subject to incalculable changes" [23: 45].

In their different papers, contributors will analyze, expose their view, hypotheses and results, showing that law serves as one of the essential references for the explanation of concepts, notions and language. They will discuss on the creativity of Law, on its foundation, and on human skills and ability to materialize, to bring to light the most adequate representation setting in the target language.

Pierre Legrand est professeur de droit à la Sorbonne, où il dirige notamment la formation spécialisée dans l'étude de la globalisation et du pluralisme juridique. Dans un essai fondé sur la philosophie du langage et après une analyse approfondie de la capacité du langage à transmettre ce 'qui est' (la réalité: le 'monde'), il en arrive à la conclusion de l'incapacité du langage, des langues et de leurs mots, face à l'unité du monde, à en rendre l'incommensurabilité. Partant de ce constat, puisque la réalité du texte est hors de portée et inappropriable, toute entreprise de traduction ('Dolmetschung') est vouée à l'échec. De même pour toute tentative de comparaison des droits: le droit étranger doit le rester.

Michel van de Kerchove est Recteur honoraire et Professeur émérite des Facultés universitaires Saint-Louis à Bruxelles. L'idée de base de l'article est de montrer que, contrairement à l'opinion répandue, les mots que le droit emprunte à la langue courante pour son usage sans les qualifier ne conservent pas la signification qu'ils ont dans celle-ci et sont parfois de 'faux amis'. La démonstration part d'une analyse critique de la référence au 'sens usuel' traité par la jurisprudence belge et passe par celle de l'autonomie conceptuelle du droit pénal par rapport aux autres branches du droit.

Professor $\mathrm{Li} \mathrm{Li}$, from China University of Political Science and Law (Beijing), investigates the feasibility, the theoretical and practical methods being used to transfer concepts, notions from English language in Victorian England to Chinese legal language. Materializing notions, concepts into another linguistic framework shows the difficulties and troubles the person translating a legal text is likely to encounter. As rightly exposed by Prof. Li Li, translators are like "dancers with shackles, translators are destined to face both opportunities for displaying their inter-linguistic talents and challenges that greatly test the limits of their abilities".

Dr Karen McAuliffe, from the University of Exeter (UK), analyzes the Court of Justice of the European Union and the way this multilingual and multicultural system has shaped a dynamic approach by which "linguistic cultural compromises" are at play, leading to a particular genre, with its own style. She shows that this hybrid system has developed a particular manner of applying EU law, defining "CJEU as a distinct, supranational order". 


\subsection{Emergence of an Interdisciplinary Discipline}

Law needs active and collaborative work to analyze and translate under real constraints with cultural challenges. Accordingly, legal translation needs to elaborate multiple and viable solutions to problems that emerge from ordinary language, and so to have culture mediation in the legal field [58]. Jurilinguistics follows Gény's argument:

"quels que soient les prétextes ou les ignorances, qui puissent expliquer ce dédain, il reste évident, pour ceux qui savent voir et juger, que le caractère, éminemment complexe, à la fois abstrait et vivant, encore incomplètement déterminé, d'ailleurs, de l'investigation juridique, requiert, pour sa pénétration et son affinement, un effort de prise en possession plus direct et plus réaliste que tout autre objet de recherché" [31: 8-9].

Dr Ling Wang, Chinese University of Hong Kong, and Professor King Kui Sin from City University of Hong Kong, tend to analyze the transfer process from Common Law to Chinese Law. Transfer a culture into a language through translation means it inevitably involves both linguistic and conceptual adjustments to accommodate the imported culture, thus always resulting in the foreignization of the target language. The focus of the present study is to set out a framework for legal translation as cultural transfer. It examines its purpose, process, principled methodologies and techniques.

Dr. Rafat Y. Alwazna, King Abdulaziz University (Kingdom of Saudi Arabia), further analyzes legal translation as being a category of its own, a legal "systemsbound" [62: 196-197] and culturally oriented [53]. Legal translation requires precision in concepts, notions and language to be correctly materialized into another linguistic framework. The contributor not only develops theoretical viewpoints but also analyzes the transfer process from Islamic Law to Western Law.

James Brannan, Senior Translator at the European Court of Human Rights, will expose the professional practice at the European Court of Human Rights. The activity of the Court is being discussed showing its supranational terminology and style, analysing legal translation and showing results with Convention-specific terms, autonomous terms, jurisprudential creations and linguistic precedent.

Professor Sin King Kui from City University of Hong Kong will show that resolving conflicting understandings is outside the only remit of translators, but also pertains to the role of the legal actors. In his paper, he shows it is a myth to consider that concepts, notions can be fully transferred in the counterpart linguistic framework. Indeed, translators exploit at best jurilinguistic resources at their disposal so that conflicting understandings can be expected to be minimized.

\section{Law as a Multifaceted Means of Communication}

Les langues sont impuissantes à rendre compte de toute la réalité sous-jacente des champs conceptuels et de l'univers qu'ils recouvrent, en particulier à l'ère de la communication planétaire, qui en exacerbe la complexité. Raison de plus pour rester 
prudents dans nos analyses et nos comparaisons, qu'elles soient d'ordre linguistique ou notionnel, sans pour autant que cela serve de prétexte aux acteurs de cette communication pour ne pas agir parce que, comme le rappelle Paul Ricoeur, 'il est toujours possible de dire la même chose autrement' [46: 16].

Concepts and notions have a peculiar tenacity with an ability to achieve stability within changing social and economic conditions [31: 42]. However, the illusion is of conservatism, rigidity and uniformity for the social structure penetrates into the architecture of the English language of the law [5]. This is the reason why every past and present society has had its own knowledge of words, and many have created or influenced words in order to reflect their particular standards and expectations.

Furthermore, there comes a linguistic insecurity as soon as someone is analysing a former cultural notion. So, the legal discourse has to be construed within a specific period of time. The interpreter is then confronted with a web closely woven around production [50: 500-501], [1: 89-101], which Eco [18: 86] describes as a multilevelled maze, representing any legal situation. Historical knowledge can be gained only by seeing the past in its continuity with the present-which is exactly what the jurist does in his practical, normative work of "ensuring the unbroken continuance of law and preserving the tradition of the legal idea" [24: 327]. Wittgenstein [63: $\S$ 129] reminds us:

The aspects of things that are most important for us are hidden because of their simplicity and familiarity. (One is unable to notice something-because it is always before one's eyes.) The real foundations of his inquiry do not strike a man at all. Unless that fact has at some time struck him.-And this means: we fail to be struck by what, once seen, is most striking and most powerful.

The legal language is, then, a complex and interesting melting pot of intrinsic and extrinsic influences, coming from cultural practices evolving within space-time and stamped with modernity [26]. Wherever one turns, individuals have maintained a written and hidden proof of this inheritance. It is only possible to decipher the language through an analysis of the historical and the silent dimensions [33: 35]:

Culture acts directly and profoundly upon behaviours, and the mechanisms, which link them, are often untold and located far beyond the voluntary control of an individual.

\section{References}

1. Aitchison, Jean. 1991. Language change: Progress or decay? Cambridge: CUP.

2. Bonvillain, Nancy. 2008. Language, culture and communication: the meaning of messages, 5 th ed. Upper Saddle River: Pearson Prentice Hall.

3. Cao, Deborah. 2003. Translating Law. Clevedon, UK: Multilingual Matters.

4. Carbonnier, Jean. 1995. Flexible droit. $8^{\mathrm{e}}$ éd. Paris: L.G.D.J.

5. Carbonnier, Jean. 1978. Sociologie juridique. Paris: Presses Universitaires de France.

6. Chesterman, Andrew. 2002. On the interdisciplinarity of translation studies. Logos and Language 3(1): 1-9. 
7. Cornu, Gérard. 1995. Français juridique et science du droit: synthèse. In Gérard Snow et Jacques Vanderlinden (dir.) Français juridique et science du droit. Bruxelles: Bruylant. pp. 11-19.

8. Crépeau, Paul A. 1993. L'affaire Daigle et la Cour suprême du Canada ou la méconnaissance de la tradition civiliste. In Ernest Caparros (dir.) Mélanges Germain Brière. Montréal: Wilson \& Lafleur, pp. 217-281.

9. Cronin, Michael. 2010. The Translation Crowd. Revista Tradumàtica. 8.

10. Cutts, Martin. 2001. Clarifying Eurolaw. Stockport: Plain Language Commission/Spectrum Press.

11. Dantzig, Charles. 2005. Dictionnaire égoüste de la littérature française. Paris: Grasset.

12. David, Aurel. 1982. Les termes élémentaires du droit. In J.-C. Gémar (dir.) Langage du droit et traduction. Québec: Conseil de la langue française. pp. 31-38.

13. David, René. 1974. Les grands systèmes de droit contemporains. $6^{\mathrm{e}}$ éd. Paris: Dalloz.

14. Didier, Emmanuel. 1990. Langues et langages du droit. Montréal: Wilson \& Lafleur.

15. Mattel, Dogan. 1997. The new social sciences: Cracks in the disciplinary walls. International Social Science Journal. 49(153): 429-443.

16. Driedger, Elmer A. 1974. The construction of statutes. Toronto: Butterworths.

17. Eco, Umberto. 2006. Dire presque la même chose. Expériences de traduction. Paris: Grasset.

18. Eco, Umberto. 1976. A theory of semiotics. Bloomington: Indiana University Press.

19. Edelman, L.B., C. Uggen, and H.S. Erlanger. 1999. The endogeneity of legal regulation: Grievance procedures as rational Myth. American Journal of Sociology 105: 406-454.

20. Fernbach, Nicole. 2005. Le mouvement pour la simplification des communications officielles. In J.C. Gémar et N. Kasirer (dir.) Jurilinguistique: Entre langues et droits. Montréal/Bruxelles: Thémis/ Bruylant, pp. 161-177.

21. Fish, Stanley. 1989. Respecter le sens commun. Paris: LGDJ.

22. Fish, Stanley. 1982. Working on the Chain Gang: Interpretation in Law and Literature, 60 Tex. L. Rev; 551-562.

23. Frank, Jérôme. 1949. Law and the modern mind. New York: Coward-McCann.

24. Gadamer, Hans A.Georg. 1989. Truth and method, 2nd rev ed. New York: Crossroad.

25. Garner, Bryan. 1987. A dictionary of modern legal usage. Oxford: Oxford University Press.

26. Gémar, Jean-Claude and Wagner, Anne (Guest Editors). 2014. Traduction juridique et jurilinguistique: discipline en voie de mondialisation. Etats et Perspectives/Legal Translation and Jurilinguistics: Globalizing Disciplines. Retrospects and Prospects. Meta Translators' Journal, vol. 58/3. (to be published in December 2014).

27. Gémar, Jean-Claude and Kasirer, Nicholas (dir.). 2005. La jurilinguistique: entre langues et droits. Jurilinguistics: Between Law and Langage. Montréal/Bruxelles: Thémis/Bruylant.

28. Gémar, Jean-Claude. 1982. Fonctions de la traduction juridique en milieu bilingue et langage du droit au Canada. In J.-C. Gémar (dir.) Langage du droit et traduction. Essais de jurilinguistique. The Language of Law and Translation. Essays on Jurilinguistics. Québec: Éditeur officiel du Québec. pp 121-137.

29. Gendreau, Isolde. 2003 (dir.) Le lisible et l'illisible. Montréal: Thémis.

30. Gentzler, Edwin. 2003. Interdisciplinary connections. Perspectives. 11(1): 11-24.

31. Gény, François. 1922. Science et Technique en Droit Privé Positif, Tome 1. Paris: Recueil Sirey.

32. Goody, Jack. 1986. The logic of writing and the organization of society. Cambridge: Cambridge University Press.

33. Hall, Edward, T. 1984. Le Langage silencieux. Paris: Editions du Seuil.

34. Hjelmslev, Louis. 1970. Language: An introduction. Whitfield trans: Francis J.

35. Iser, Wolfgang. 1994. On Translability. Surfaces 4(307): 5-13.

36. Kasirer, Nicholas. 2003. (dir.) Le droit civil, avant tout un style? Montréal: Les Éditions Thémis.

37. Kevelson, Roberta. 1996. Pierce, science, signs, vol. 9. New York: Peter Lang.

38. Kevelson, Roberta. 1988. The law as a system of signs. New York: Peter Lang.

39. Legrand, Pierre. 2005. Issues in the Translability of Law. In Nation, language, and the ethics of translation, ed. Sandra Bermann, and Michael Wood, 30-50. Princeton University Press: NewJersey.

40. Lerat, Pierre. 1995. Les langues spécialisées. Paris: Presses universitaires de France.

41. MacCormick, Neil. 1992. A Deductivist Rejoinder to a Semiotic Critique. International Journal for the Semiotics of Law V/14: 215-224.

42. McAuliffe, Karen. 2009. Translation at the court of Justice of the European Communities. In Translation issues in language and law, ed. Frances Olsen, et al., 95-115. Basingstoke: Palgrave. 
43. Monjean-Decaudin, Sylvie. 2010. Territorialité et extraterritorialité de la traduction du droit. Meta 55(4): 693-711.

44. Nehrot, Patrick. 1993. Law, writing, meaning: An essay in legal hermeneutics. Edinburgh: Edinburgh Press.

45. Ost, François et Michel de Kerchove. 1990. Interprétation. In Vocabulaire fondamental du droit. Paris: Sirey. Archives de philosophie du droit, t. 35. 165-190.

46. Ricoeur, Paul. 2004. Sur la traduction. Paris: Bayard.

47. Sacco, Rodolfo. 1999. Langue et droit. In R. Sacco et L. Castellani (dir.) Les multiples langues du droit européen uniforme. Torino. L'Harmattan. pp. 163-185.

48. Sacco, Rodolfo. 1991. Legal Formants: A dynamic approach to comparative law (II). American Journal of Comparative Law 39: 388-399.

49. Šarčević, Susan. 1997. New approach to legal translation. The Hague: Kluwer.

50. Schauer, Frederik. 1992. Law and language. New York: New York University Press.

51. Serres, Michel. 1990. Le contrat naturel. Paris: Éditions François Bourin.

52. Snell-Hornby, Mary. 2006. The turns of translation studies: New paradigms or shifting viewpoints? Amsterdam/Philadelphia: John Benjamins.

53. Snell-Hornby, Mary. 1990. Linguistic transcoding or cultural transfer? A critique of translation theory in Gemarny. In Translation, history, and culture, ed. S. Bassnett, and A. Lefevere, 79-86. London: Pinter.

54. Solan, Lawrence. 1993. The language of judges. Chicago: University of Chicago Press.

55. Steiner, George. 1992. After Babel. Oxford: Oxford University Press.

56. Tiersma, Peter. 2000. Legal Language. Chicago: University of Chicago Press.

57. Vanderlinden, Jacques. 1999. Contemporary Law. In Canadian Reports to the 1998 International Congress of Comparative Law. Bristol/Cowansville: Les Editions Yvon Blais, pp. 25-68.

58. Wagner, Anne \& Gémar, Jean-Claude (Guest Editors). 2014. Decision-Making in Legal Translation, Interpretation and Speech Act-Legal Semiotic Cultural Mediation Techniques. Semiotica (to be published in 2014).

59. Wagner, Anne. 2002. The legal discourse of the common law: A game of chess. International Journal for the Semiotics of Law 15(4): 345-360.

60. Wagner, Anne. 1999. Les maux du droit et les mots pour le dire. Unesco ALSED-LSP Newsletter 22(1/47): 40-70.

61. Warnke, Georgia. 1992. Justice and interpretation. London: Polity Press.

62. Weisflog, W.E. 1987. Problems of legal translation, 179-219. Comparative Law: Swiss Report Presented at the XIIth International Congress of.

63. Wittgenstein, Ludwig. 1968. Philosophical investigation. Oxford: Trans. GEM Anscombe. Basil Blackwell. 